\title{
THE STUDY OF THE LEVEL OF ARTISTIC EXPERIENCE DEVELOPMENT OF YOUNG TEENAGERS ON THE BASE OF POLYART APPROACH
}

\author{
Oksana Ovsyannikova \\ Department of Arts \\ Tyumen State University \\ 6 Volodarskogo str., Tyumen, Russian Federation, 625003 \\ sergeiovsiannikov@yandex.ru
}

\begin{abstract}
The aim of this research is the elaboration of diagnostic instruments for revelation of the level of artistic experience development of young teenagers on the base of polyart approach and also analysis of diagnostic arrangements with fifth-year pupils. The criteria, parameters and level of artistic experience development of teenagers were described in the article; the author's diagnostic tasks were elaborated according to the polyart approach. The diagnostic methods (testing, essay, questionnaire, creative tasks) were determined for each parameter. The diagnostic arrangements at institutions of general education allowed make a conclusion about the necessity to raise the level of artistic experience development of pupils and to prognosticate the methods that favor it.
\end{abstract}

Keywords: artistic experience, polyart approach, diagnostic methods (testing, essay, creative tasks), young teenagers.

\section{Introduction}

The study of the level of artistic experience development of young teenagers is caused by the necessity of harmonization of the sphere of scientific and artistic thinking of the person. The world cognition can be realized by both logic way and using imaginative-emotional sphere. Both these ways mutually add each other. Unfortunately, in last decade technocratic approach that does not take into account artistic, emotional development of each person is maintained more and more in education and society $[1,2]$. The art, on the contrary, is directed in the whole its diversity of types and genres on the widening of cognitive sphere of pupils by the means of artistic image. Even B. M. Nemensky wrote that "there is a kind of human activity that also creates the integral picture of the world... in the unity of thought and feeling, in the system of emotional images instead of logic laws, - it is art. And such a way of integral consciousness of the life is accessible even for a child..." $[3,16]$. The author states that the science and art cannot be considered as the higher and lower stages of spiritual phenomenology, because it can lead to the great losses in the moral education of growing generation [3].

The effective development of artistic experience of school children provides the diagnostic study that is the aim of this work. Several scientists considered the problem of the personal artistic experience development. N. N. Digtyar has elaborated the criteria and levels of formation of pupils' artistic experience by the means of folk picture [4]. V. G. Averochkin presented the levels of teens' artistic experience development: passive, reproductive, active, active-creative [5]. M. A. Gorbunova has defined the main parameters of the personal artistic experience at the music lesson: the totality of human artistic interests; imaginative-sensual personal sphere; general artistic knowledge, abilities and skills; the system of internal artistic values [6]. From our point of view, the diagnostics and development of the pupils' artistic experience must be realized on the base of polyart approach in pedagogy of art, because the very notion "artistic experience" provides the consideration of the different kinds of art, their interconnection. The importance of polyart approach in personal development, especially in its artistic experience development is stated by many scientists (E. P. Kabkova, L. G. Savenkova, N. G. Tagilceva, N. P. Shishlyannikova, B. P. Yusov) [7-11].

The study is devoted to the successive revelation and consideration of the level of artistic experience development of the young teenagers. The criteria, parameters and levels of the pupils' artistic experience development were determined on the base of theoretical analysis of the literature about this problem. The author's diagnostic tasks for teenagers were elaborated for each parameter on the base of polyart approach. The carrying out of diagnostic arrangements on the base 
of general education institutions of the city Tyumen allowed make a conclusion about the necessity of development of artistic experience of the young teenagers, about elaboration of forming tasks on the base of polyart approach.

\section{Materials and methods}

The methodology of research is based on the system approach application that allows study the artistic experience as multicomponent personal education in the unity of cognitive, imaginative-sensual and creative components. The study of the essence of the notion "artistic experience" led to the use of polyart approach that favored the more objective elaboration of diagnostic instruments, corresponded to the essence of the studied quality of teenagers. Polyart approach is based on the united nature of all kinds of arts $[12,13]$. The applied diagnostic methods (testing, essay, questionnaire, creative tasks) were remarkable for their accessibility for the young teen children and also favored the revelation of studied quality.

The theoretical analysis of studied notion in interpretations of the different authors was carried out to define the criteria, parameters and levels of school children's artistic experience development that has led to the formulation of own definition of the notion "artistic experience".

M. A. Gorbunova considers the artistic experience as dynamically developing unity of imaginative-sensual personal heritage (esthetic perception, esthetic, attitude, feelings and emotions), personal general artistic knowledge, abilities and skills, positive attitude to the art as a result of the direct interaction with the world of artistic creativity [6]. Digtyar N. N. presents the artistic experience as the personal education, specific type of esthetic experience, the result of artistic-esthetic personal activity that forms the spiritual-practical human essence [4]. The author also defines the components of artistic experience: the presence of personal artistic interests; development of emotional-sensual sphere; value attitude to the works of art; artistic knowledge, abilities, skills; experience of creative activity [4].

"According to the analysis of different definitions of the term "art experience" with its constituents, the author can clarify the term "art experience of teens" which can be treated as a developing personal formation, which is based on the unity of art knowledge about different kinds of art, emotional tenderness by their perception, wish to communicate with works of arts and positively relate to their value. According to refined definition and constituents of art experience, the author identified its components: informative, figurative and sensual, evaluative and creative" [14].

\section{Experimental studies}

The experience-searching work on the development of artistic experience was carried out on the base of school № 68 of the city Tyumen and included several stages: stating (initial diagnostics), developing (carrying out of activities) and control (final diagnostics).

This work describes the first stage, within which the initial diagnostics of the level of artistic experience development of the children of the young teen age was realized. According to the results of diagnostics, the activities for development of artistic experience in children were elaborated. At the second stage the developing activities with fifth-year pupils were realized [14]. At the third stage the final diagnostics was realized, the results of the study were analyzed.

Diagnostic study included 60 children of the young teen age, fifth-year pupils of the school № 68 of the city Tyumen.

The definition of the notion "artistic experience" that has been formulated by the author allowed define its components: cognitive, imaginative-sensual, value, creative. The components were the criteria of the artistic experience development of pupils.

At the revelation of each component and also for elaboration of diagnostic tasks the age features of young teenagers were taken into account. Such age features of young teenagers as inquisitiveness, striving for self-expression, including the need for the verbal expression of own feelings and emotions, openness to the new, striving for independence, initiative influence the development of their artistic experience $[15,16]$. The important role in the development of teenagers' artistic experience is played by the leading type of activity - communication. In this case it is not only 
communication with peers but also the artistic communication that provides dialog, co-authorship with author, hero of the different works of art [17].

The reveled criteria are concretized by the parameters.

Cognitive criterion corresponds to the parameter "presence of general artistic knowledge".

The following diagnostic task was elaborated for realization of this parameter:

Test on the history and theory of art (its different types), corresponded to the age of fifthyear schoolchildren. Let's offer several questions of the test. Schoolchildren had to choose the correct variant of the answer.

1. What is folklore?

- folk creativity;

- creativity of composers;

- author's song.

2. Expressive means of dance are....?

- word;

- music;

- movement.

3. Who is responsible for the staging of performance, film, show?

- script writer;

- dramatist;

- director.

4. Expressive means of painting are...?

- picture;

- figure;

- paints.

5. Name the author of the work "Sistine Madonna":

- Michelangelo;

- Raphael;

- Leonardo da Vinci;

- Sandro Bottichelli.

6. The genre of painting that is a component of historical and mythological genre:

- animalistic;

- battle;

- home;

- still life.

7. Artistic style that appeared in Middle age, which architectural constructions look like the "open stone books":

- baroque;

- modern;

- gothic;

- eclecticism.

8. The direction in painting and music of the second half of XIX-beginning of XX century, born in France that transfers the impression of the seen:

- expressionism;

- classicism;

- postimpressionism;

- impressionism.

The imaginative-sensual criterion corresponds to the parameter "ability to emotional respond to the works of art and expression of own emotions in imaginative form".

Diagnostic task: schoolchildren received for perception the different works of art: A. I. Khachaturian "Adagio of Spartak and Frigia", reproduction of the picture by C. Monet "Pond with water lilies", image of architectural composition, fragment of ballet "Swan" by 
Maya Plisetskaya, fragment of the film-opera "You are my delight, you are my torment" on the opera "Tosca" by G. Puccini.

Schoolchildren are acquainted with them. Then they choose the most pleasant one for them and write essay (own impressions) about this work of art.

The value criterion corresponds to the parameter "wish to communicate with art and positive attitude to the artistic values"

The artistic values (according to the legislation of RF) are the values and categories of objects that constitute the artistic heritage. There are masterpieces of the masters of arts of the present and past.

Diagnostic task: questionnaire.

The questionnaire includes the following questions:

1. Have you the wish to communicate with the works of art? if yes, it is:

- often;

- sometimes;

- from time to time (seldom).

2. Have you the favorite kind of art?

3. Have you the favorite work of art? Why?

4. Why this work of art is valuable for you?

5. Look at the picture by P. A. Fedotov "Match-making of the major", what sense, from your point of view, was inserted in this work of art by the author?

6. What sense has this picture for you?

- positive;

- negative;

- neutral.

7. How do you think, what this picture teaches spectators?

The creative criterion corresponds to the parameter "readiness and ability to create the artistic-creative product".

Diagnostic (creative) task:

1. To create independently the computer collage (or slide show) of the masterpieces of the different kinds of art (found in internet). Teenagers must independently choose 10 works of art that they consider as masterpieces, then to ground their choice.

2. To write the short novel about the famous picture (B. M. Vasnetsov "The deathless Koschei").

The criteria, parameters and diagnostic methods are presented in the Table 1.

Table 1

The criteria, parameters and diagnostic methods

\begin{tabular}{cccc}
\hline Cognitive & Imaginative-sensual & Value & Creative \\
\hline $\begin{array}{c}\text { Presence of general artistic } \\
\text { knowledge }\end{array}$ & $\begin{array}{c}\text { Ability to emotional response } \\
\text { to the work of art and to } \\
\text { expression of the own feelings } \\
\text { in imaginative form }\end{array}$ & $\begin{array}{c}\text { Wish to communicate with the } \\
\text { work of art and positive attitude } \\
\text { to the artistic values }\end{array}$ & $\begin{array}{c}\text { readiness and ability to create } \\
\text { the artistic-creative product }\end{array}$ \\
\hline Dest & Diagnostic methods and tasks & Questionnaire & Creative task
\end{tabular}

Each parameter was assessed according the point system. Teenagers could receive from 0 to 2 points for each task, in total by the sum of all tasks they could receive from 0 to 10 points (because 2 tasks were offered in the creative criterion).

The following levels of development of artistic experience of schoolchildren were defined:

High (8-10 points) - significant volume of general artistic knowledge; is able to the emotional response to the works of art and to the expression of own feelings in bright imaginative form, using epithets, comparisons and so on; the wish to communicate with the works of art is expressed rather often, he/she understands the value and sense of perceived work of art, it has a positive mean- 
ing for he/her; is able (has a wish) to create the artistic-creative product, the ready product has a deep sense and artistic value (is constructed compositionally, nicely formed, has the elements of novelty and originality in content and form).

Middle (4-7 points) - the general knowledge is surface and selective, is able to the response to the works of art but expresses the own feelings by the "dry", non-emotional language, does not use epithets, imaginative comparisons, metaphors; the wish to communicate with the work of art is manifested sometimes, he/she understands that the perceived work of art has value but does not insert the concrete sense in it, the work of art has a neutral value for schoolchild; is ready (has a wish) to create artistic-creative product but this product has the sense and artistic defects; it has not enough originality, is standard by form and content).

Low ( $0-3$ points) - the absence of general cultural knowledge, lack of development of the ability to emotional response to the work of art and expression of the own feelings in imaginative form; the wish to communicate with the work of art is expressed from time to time, he/she does not understand the value and sense of perceived work of art, it has the negative value for him/her; does not express the readiness (does not wish) and ability to create the artistic-creative product.

\section{Results of the research}

After the carrying out of diagnostic arrangements the results were analyzed. The results of initial diagnostics are presented below.

The levels of artistic experience development of the young teenagers at the initial stage of diagnostics are presented in the Table 2.

Table 2

The levels of artistic experience development of the young teenagers at the initial stage of diagnostics

\begin{tabular}{ccc}
\hline Levels & Number of school children & Percent ratio \\
\hline High & 0 & $0 \%$ \\
Middle & 22 & $36,7 \%$ \\
Low & 38 & $63,3 \%$
\end{tabular}

The data of initial diagnostics demonstrated that the pupils were characterized with predominantly low and middle level of artistic experience development, the higher level was not revealed. In the process of carrying out of diagnostic tasks the pupils faced with such problems as the low level of general artistic knowledge, inability to emotional response to the works of art, to expression of the own feelings in imaginative form. Many teenagers could not make a collage, because they did not know, what works of art can be related to the masterpieces, several schoolchildren could not write the short story about the perceived picture and also to conscious the sense, inserted by the author in the work of art. The qualitative and quantitative analysis of diagnostic of the teenagers' artistic experience revealed the necessity of its development.

\section{Discussion}

The results of diagnostic study demonstrated, firstly, the insufficient level of the artistic experience development of young teenagers; secondly, allowed plan and prognosticate the methods that favor the development of aforesaid quality of schoolchildren on the base of polyart approach (the method of "musical graphics" [18], heuristic work with plot [19], method of comparison of the creative images of different kings of art, collage method and so on); thirdly, the diagnostic results have proved one more time the problem of disharmony between the spheres of scientific and artistic thinking of pupils.

\section{Conclusions}

According to the specified definition and components of artistic experience, its constituents were separated: cognitive, imaginative-sensual, value and creative.

The parameters of each criterion, determined on the base of separated components of artistic experience of teenagers, were defined. The author's diagnostic tasks were elaborated for each parameter. 
The age features of the young teenagers that influence the development of their artistic experience were considered: the striving for self-expression, including the need of verbal expression of the own feelings and emotions, self-consciousness, openness to the new and so on.

The communication with the different kinds of art within the polyart approach can have a positive influence on the development of teenager's artistic experience [20], that is on the development of his/her value sphere due to the revelation of the main sense and common human needs, laid in the different works of art; on the development of his/her creative sphere due to the self-expression at the creation of artistic-creative products; on the development on his/her imaginative-sensual sphere by the perception, comparison and analysis of the different kinds of art; and also on the development of teenager's cognitive sphere by acquiring knowledge about the different kinds of art, their specificity, history of creation and so on.

\section{Acknowledgments}

We express gratitude to the administration and teachers of the secondary school № 68 of the city "Tyumen" for the assistance in carrying out of diagnostic arrangements with pupils.

\section{Reference}

[1] Belov, K. O. (2012). Tekhnokraty v obrazovanii. Avialable at: http://konst-belov.livejournal. com/7537.html

[2] Uilson, A. U. (2005). Psihologiya ehvolyucii. Kyiv: Sofiya, 304.

[3] Nemensky, B. M. (1981). Mudrost' krasoty: O probleme ehsteticheskogo vospitaniya. Moscow: Prosveshchenie. 268.

[4] Digtyar', N. N. (2014). Kriterii i urovni sformirovannosti hudozhestvennogo opyta uchashchihsya srednej shkoly sredstvami narodnoj kartiny. Fundamental'nye issledovaniya, 3-3, 575-579.

[5] Averochkin, V. G. (1988). Formirovanie obshchestvennoj aktivnosti podrostkov v processe vneklassnyh muzykal'nyh zanyatij. Moscow, 16.

[6] Gorbunova, M. A. (2007). Razvitie hudozhestvennogo opyta podrostkov na urokah muzyki i vneklassnyh zanyatiyah. Moscow, 185.

[7] Kabkova, E. P. (2012). Etapy stanovleniya polihudozhestvennogo podhoda v obrazovanii. Aktual'nye problemy muzykal'no-pedagogicheskogo obrazovaniya. Moscow: MPGU, 115.

[8] Savenkova, L. G. (2011). Vospitanie cheloveka v prostranstve mira i kul'tury: Integraciya v pedagogike iskusstva. Moscow: MAGMU-RANHiGS, 156.

[9] Tagil'ceva, N. G. (2015). Polihudozhestvennyj podhod v razvitii strategii polihudozhestvennogo obrazovaniya. Pedagogicheskoe obrazovanie v Rossii, 12, 91-94.

[10] Shishlyannikova. N. P. (2014). Polihudozhestvennaya podgotovka budushchego pedagoga-muzykanta k rabote v shkole. Vestnik Polockogo gosudarstvennogo universiteta. Seriya: Pedagogicheskie nauki, 15, 21-26.

[11] Yusov, B. P. (2015). Sovremennaya koncepciya obrazovatel'noj oblasti «Iskusstvo» v shkole. Avialable at: http://www.studfiles.ru/preview/4190025/

[12] Yusov, B. P. (1990). Vzaimodejstvie i integraciya iskusstv v polihudozhestvennom razvitii shkol'nikov. Lugansk, 175.

[13] Ovsyannikov, M. F. (Ed.) (1983). Kratkij slovar' po ehstetike. Moscow: Prosveshchenie, 223.

[14] Ovsyannikova, O. A. (2016). Development of the art experience of teenagers by the ways of art synthesis. Austrian Journal of Humanities and Social Sciences, 7-8, 15-18.

[15] Piazhe, Z. H., Inhel'der, B. (2003). Psihologiya rebenka. Saint Peterburg: Piter, 159.

[16] Fel'dshtejn, D. I. (Ed.) (1987). Psihologiya sovremennogo podrostka. Moscow: Pedagogika, 240.

[17] Bahtin, M. M. (2000). Avtor i geroj. K filosofskim osnovam gumanitarnyh nauk. Saint Peterburg: Azbuka, 337.

[18] Rainer, O. (1925). Musikalische Graphik: Studien und Versuche uber die Wechselbeziehungen zwische Ton- und Farbharmonien. Wien, 117.

[19] Zhdanova, S. N. (2006). K voprosu o roli polihudozhestvennyh metodov v processe ehsteticheskogo osvoeniya mira uchashchimisya. Avialable at: http://www.emissia.al.ru

[20] Melik-Pashaev, A. A. (2006). Psihologicheskie osnovy hudozhestvennogo razvitiya. Moscow: MGPPU, 215. 